\title{
Socioeconomic Factors in Adherence to HIV Therapy in Low- and Middle-income Countries
}

\author{
Karl Peltzer ${ }^{1,2,3}$, Supa Pengpid ${ }^{2,3}$ \\ 'HIV/AIDS/SIT/and TB (HAST), Human Sciences Research Council, Pretoria, South Africa; ${ }^{2}$ Department of Psychology, \\ University of Limpopo, Turfloop, South Africa; ${ }^{3}$ ASEAN Institute for Health Development, Madidol University, Salaya,
} Phutthamonthon, Nakhonpathom, Thailand 73170

\begin{abstract}
It is not clear what effect socioeconomic factors have on adherence to antiretroviral therapy (ART) among patients in low- and middle-income countries. We performed a systematic review of the association of socioeconomic status (SES) with adherence to treatment of patients with HIV/AIDS in low- and middleincome countries. We searched electronic databases to identify studies concerning SES and HIV/AIDS and collected data on the association between various determinants of SES (income, education, occupation) and adherence to ART in low- and middle-income countries. From 252 potentially-relevant articles initially identified, 62 original studies were reviewed in detail, which contained data evaluating the association between SES and adherence to treatment of patients with HIV/AIDS. Income, level of education, and employment/occupational status were significantly and positively associated with the level of adherence in 15 studies (41.7\%), 10 studies (20.4\%), and 3 studies (11.1\%) respectively out of 36, 49, and 27 studies reviewed. One study for income, four studies for education, and two studies for employment found a negative and significant association with adherence to ART. However, the aforementioned SES determinants were not found to be significantly associated with adherence in relation to 20 income-related (55.6\%), 35 education-related (71.4\%), 23 employment/occupational status-related (81.5\%), and 2 SES-related (100\%) studies. The systematic review of the available evidence does not provide conclusive support for the existence of a clear association between SES and adherence to ART among adult patients infected with HIV/ AIDS in low- and middle-income countries. There seems to be a positive trend among components of SES (income, education, employment status) and adherence to antiretroviral therapy in many of the reviewed studies.
\end{abstract}

Keywords: Antiretroviral therapy, highly active; Education; Employment; Income; Occupations; Social class

\section{INTRODUCTION}

The clinical efficacy of antiretroviral therapy (ART) in suppressing the HIV virus and improving survival rates for those living with HIV has been welldocumented (1-3). However, successful antiretroviral therapy is dependent on sustaining high levels of adherence (correct dosage, taken on time, and in the correct way-either with or without food). The minimum level of adherence required for antiretro-

Correspondence and reprint requests:

Professor Karl Peltzer

Human Sciences Research Council

Private Bag X41

Pretoria 0001

South Africa

Email: KPeltzer@hsrc.ac.za viral drugs to work effectively is 95\% (4). Although more potent antiretroviral regimens can allow for effective viral suppression at moderate levels of adherence, no or partial adherence can lead to the development of drug-resistant strains of the virus (5-7). Adherence to ART is influenced by factors associated with the patient, the disease, the therapy, and the relationship of the patient with healthcare provider (8-10). Patient-related factors include socioeconomic status (SES) $(8,10)$.

A review of studies since 2005 on SES and adherence to ART primarily in high-income countries, did not provide conclusive support for a clear association between SES and adherence (8). However, it is not clear what effect socioeconomic factors have on adherence to ART in low- and middle-income 
countries. A possible association between SES and adherence to ART among HIV patients may have an impact on the success of their treatment $(8,10)$.

\section{MATERIALS AND METHODS}

Literature search

We performed a systematic search of the literature to identify reviews and original studies that reported data on the impact of SES on adherence to ART. The relevant studies were identified by the use of electronic databases, such as MEDLINE, EMBASE, SCI Web or Science, NLM Gateway, and Google Scholar. The last search was conducted in November 2011. In addition, relevant articles from the list of references of the initially-retrieved papers were identified. Studies conducted only in low- and middle-income countries were included, according to World Bank classifications (11). Five different search strategies using the following key words were employed: (i) Socioeconomic status AND (HIV OR AIDS) AND (compliance OR adherence), (ii) (Compliance OR adherence) AND (HIV OR AIDS) AND determinants, (iii) (AIDS OR HIV) AND (compliance OR adherence) AND education AND/OR income AND/OR occupation, (iv) (AIDS OR HIV) AND (compliance OR adherence) AND determinants, and (v) (AIDS OR HIV) AND (compliance OR adherence).

Defining socioeconomic status (SES) is difficult because a single, consistent unit of measurement was not used in the studies reviewed. Further, a debate exists in the public-health arena on the appropriate components of socioeconomic status and methods of measurement (12). Krieger et al. (13) have argued that it is important to distinguish two different components of socioeconomic position (actual resources and prestige or rank-related characteristics), and they preferred the use of the term 'socioeconomic position' instead of 'socioeconomic status'. In addition, they argued that it is important to collect data at the individual, household and neighbourhood level $(12,13)$. Additional points emphasized included that data on individuals supported from 'annual family income' should be collected, measurements should incorporate the recognition that socioeconomic position can change over a lifetime, and measures of socioeconomic position may perform differentially based on racial/ethnic group and gender background $(12,13)$. Most of the reviewed articles did not attend to these complexities, rather used one to three measures of SES, most often simplistic measures of income, education, and occupation or employment status. The reviewed articles were analyzed with the understanding that the complexities present in SES highlighted by Krieger et al. (13) should ideally be incorporated in future studies designed to tease out the relationship between SES and adherence to ART in low- and middleincome populations. Meanwhile, the term SES is used in this article rather than socioeconomic position, simply because this is how these measures were discussed by the authors in the papers reviewed (12). SES reflects different aspects of social stratification, and the traditional indicators at the individual level have been income, education, and occupation $(14,15)$. There is no single-best indicator of SES suitable for all study objectives and applicable at all time-points in all settings. Each indicator measures different, often related aspects of socioeconomic stratification and may be more or less relevant to different health outcomes and at different stages in the course of life (15). Galobardes et al. (16) described the theoretical basis of the following three indicators used for measuring SES:

(a) Education attempts to capture the knowledgerelated assets of a person. As formal education is normally completed in young adulthood and is strongly determined by parental characteristics, it can be conceptualized within a course of life framework as an indicator that, in part, measures socioeconomic position (SEP) in early life (16).

(b) Income is the indicator of SEP that most directly measures the material resources component (16).

(c) Occupation represents Weber's notion of SEP as a reflection of a person's place in society relating to their social standing, income, and intellect (16).

\section{Selection of studies}

The inclusion and exclusion criteria used for the reviewed studies were set before the literature search. Studies included in our study concerned only individual HIV-infected adult patients and their adherence to antiretroviral therapy. Reviews and editorials were not included in our systematic review. Studies that focused on HIVinfected illicit and/or licit drug-users and/or those with severe mental illness were excluded since such persons may need more creative approaches than other patients to ART adherence that differentiates them from the general popu- 
lation (8,17-19). Two authors of the present article evaluated the eligibility studies obtained from the literature search using a predefined protocol. The two authors worked independently to scan all abstracts and obtained full-text articles. In cases of discrepancy, agreement was reached by consensus.

\section{Data extraction}

Two authors of the present article independently extracted and compiled the data. For each identified study that met the selection criteria, details were extracted on study design, characteristics of study population, data relevant to SES, the measure of adherence, the overall adherence, and findings regarding the association between determinants of SES and adherence on to an Excel spreadsheet. In this review, three parameters as major factors contributing to SES were assessed, namely income, education, occupation/employment status and their association with adherence to ART.

The following diagram presents the various steps in the process of selecting studies.

\section{RESULTS AND DISCUSSION}

The literature search identified 252 potentiallyrelevant studies, from which we further reviewed 62 studies with original data. In Annexure A-F, the characteristics of 62 studies that were included in the systematic review are presented by region and country. The year of publication of the studies ranged from 2002 to 2011. There was considerable variability across the studies in setting and patient population, largely because these were conducted in different low-resource settings, with different cultures, incomes, and education levels (Table 1).

Regarding the study design, 44 cross-sectional $(21,24,26,28-31,33-37,41,42,47-49,53,55,56,58-72$, $74-76,78-82), 19$ longitudinal $(22,25,27,32,38$ $40,43-46,50-52,54,57,77)$, and two case-control $(23,73)$ studies were included in the review. The average number of patients was 400 per study in the total of 62 studies (ranging from 53 to 2,381, depending on the study setting).

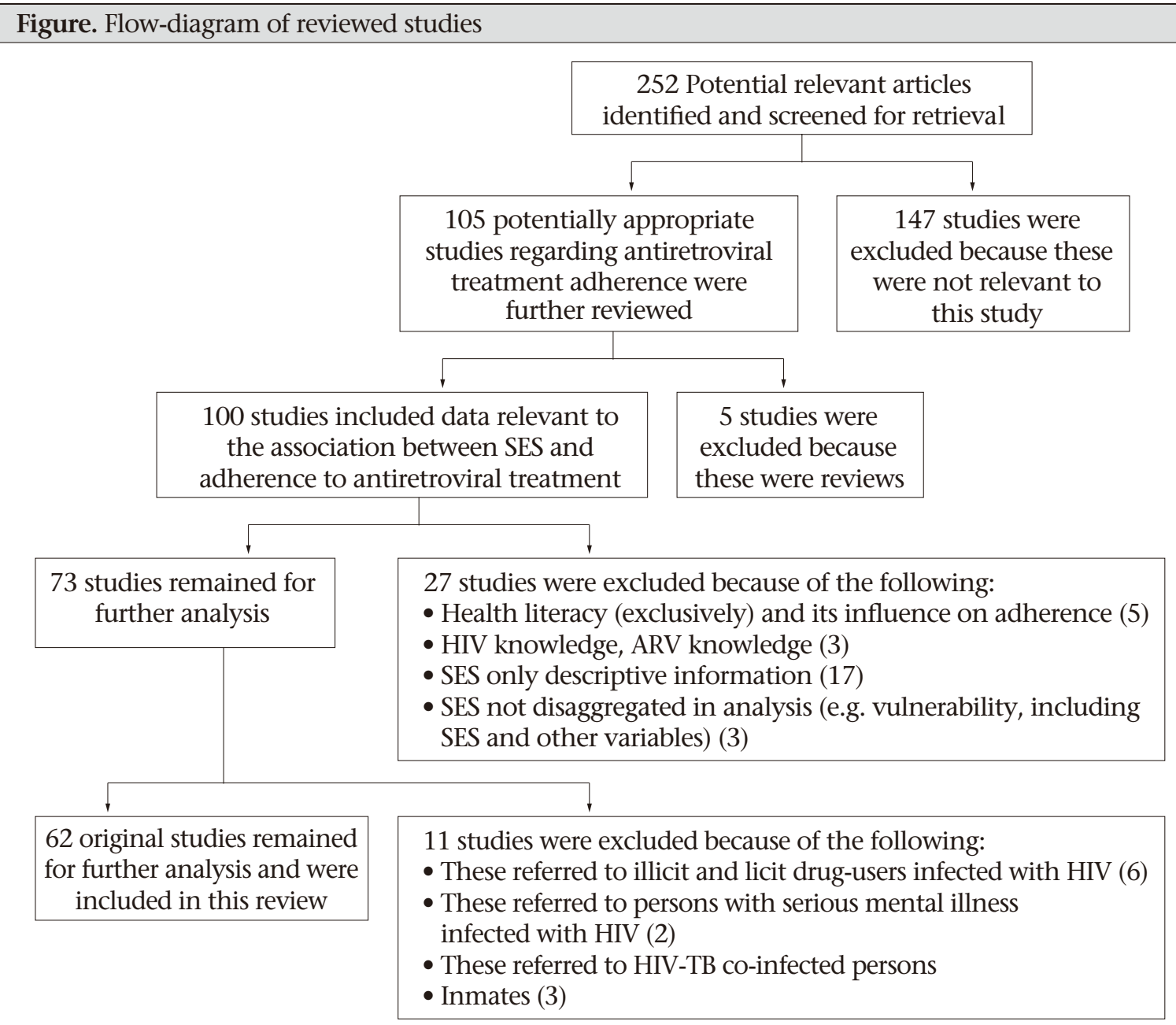


Studies varied in the measurement of adherence (pills per dose, doses per day, days of treatment per week, time schedule for pill-refill, etc.) and used different cutoff points of adherence (from $80 \%$ to $100 \%$ of dosage) to dichotomize the patients between adherence and non-adherence to ART. Two studies focused directly on the association between SES or its main determinants analyzed as a group and adherence $(40,78)$. The available reported data regarding the method, with which adherence to antiretroviral treatment was measured, and the data on overall adherence are presented in Annexure A-F. In 50 out of 62 studies included in the review, self-report by the patients was the main measure of adherence to treatment $(21,22,24,26,27,29-32,34$ $37,39,41,42,44-49,51,53,56,58-69,70-82)$; six studies used pill counts, MEMS, pharmacy refills as the main measures $(23,40,43,54,55,57)$, and in six

\begin{tabular}{|c|c|c|c|c|}
\hline \multirow[b]{2}{*}{ Country } & \multicolumn{2}{|c|}{ Education } & \multicolumn{2}{|c|}{ Income } \\
\hline & $\begin{array}{c}\text { Adult } \\
\text { literacy (\%) }\end{array}$ & $\begin{array}{l}\text { Primary school } \\
\text { enrollment rate: } \\
\text { Male/Female }\end{array}$ & $\begin{array}{l}\text { Gross national } \\
\text { income per capita } \\
\text { (PPP int. \$) }\end{array}$ & $\begin{array}{c}\text { Living on }<1 \$ \\
\text { (PPP int. \$) a } \\
\text { day (\%) }\end{array}$ \\
\hline Botswana & 83 & $86 / 88$ & 12,840 & - \\
\hline Brazil & 90 & $95 / 93$ & 10,200 & 5.2 \\
\hline Burkina Faso & 29 & $67 / 59$ & 1,170 & 56.5 \\
\hline Cameroon & 76 & $97 / 86$ & 2,190 & 32.1 \\
\hline China & 94 & - & 6,890 & 15.9 \\
\hline Columbia & 93 & $93 / 80$ & 8,600 & 16.0 \\
\hline Costa Rica & 96 & - & 10,930 & 2.0 \\
\hline Cuba & 100 & $99 / 99$ & - & - \\
\hline Dominican Republic & 88 & $92 / 82$ & 8,110 & 4.4 \\
\hline Ethiopia & 36 & $85 / 80$ & 930 & 39.0 \\
\hline India & 63 & $91 / 88$ & 3,250 & 41.6 \\
\hline Ivory Coast & 55 & $62 / 52$ & 1,640 & 23.3 \\
\hline Jamaica & 86 & $82 / 79$ & 7,230 & $<2.0$ \\
\hline Kenya & 87 & $82 / 83$ & 1,570 & 19.7 \\
\hline Mali & 26 & $79 / 66$ & 1,190 & 51.4 \\
\hline Nigeria & 60 & $64 / 58$ & 2,070 & 64.4 \\
\hline Papua New Guinea & 60 & - & 2,260 & - \\
\hline Rwanda & 70 & $95 / 97$ & 1,060 & 76.6 \\
\hline Senegal & 42 & $72 / 74$ & 1,810 & 33.5 \\
\hline South Africa & 95 & $87 / 88$ & 10,050 & 26.2 \\
\hline The Gambia & 45 & $67 / 71$ & 1,330 & 34.3 \\
\hline Thailand & 94 & $91 / 89$ & 7,640 & $<2.0$ \\
\hline Uganda & 75 & 96/99 & 1,190 & 51.5 \\
\hline United Republic of Tanzania & 73 & $96 / 97$ & 1,350 & 88.5 \\
\hline Zambia & 71 & $96 / 92$ & 1,280 & 64.3 \\
\hline
\end{tabular}

Table 2. Summary of studies on the association between the main components of socioeconomic status and adherence to antiretroviral therapy

\begin{tabular}{|c|c|c|c|c|}
\hline SES component & $\begin{array}{c}\text { Number of } \\
\text { studies } \\
\mathrm{N}\end{array}$ & $\begin{array}{c}\text { Positive } \\
\text { association } \\
\mathrm{N}(\%)\end{array}$ & $\begin{array}{l}\text { Negative } \\
\text { association } \\
\mathrm{N}(\%)\end{array}$ & $\begin{array}{c}\text { No } \\
\text { association } \\
\mathrm{N}(\%) \\
\end{array}$ \\
\hline Education & 49 & $10(20.4)$ & $4(8.2)$ & 35 (71.4) \\
\hline Income & 36 & $15(41.7)$ & $1(2.8)$ & $20(55.6)$ \\
\hline Occupation/employment & 27 & $3(11.1)$ & $2(7.4)$ & $22(81.5)$ \\
\hline SES & 2 & 0 & 0 & $2(100)$ \\
\hline
\end{tabular}


studies both self-report and objective adherence measures $(25,28,33,38,50,52)$ were used.

The main parameters affecting SES (income, education, occupation) were only examined as a group comprising SES in two studies but, in 61 studies, these were rather regarded as socioeconomic characteristics. Therefore, many studies lacked data concerning some of the parameters. There were insufficient data regarding income in 26 studies $(22,28,29,31,33,37,38,41,47,48,50,51,53,54$, $56,60,68-70,72,74,75,80-82)$ and educational level in $14(26,28,30,37,39-41,46,59,61,62,65,68)$ of the 62 reviewed studies (Some of the studies had data on income but not on education, and others had the reverse). Employment and/or occupational status was assessed in 28 studies (22$24,28,29,31,34-37,39-42,44,45,53,54,58,59,61,67-$ $69,70,77,78,81,82)$. However, no data were given on occupational status or working position in 18 of those 28 studies.

The main findings regarding the analysis of the association of SES or the various components of SES and adherence were as follows: income, level of education, and employment/occupational status were significantly and positively associated with the level of adherence in 15 studies (41.7\%) $(21,24,26,32,39,43,46,49,62,63,65-67,76,78)$, 10 studies $(20.4 \%)(33,35,53,66,69,71-73,75,77)$, and three studies $(11.1 \%)(28,29,77)$ respectively out of 36, 49, and 27 studies reviewed. Most significant findings refer to a positive association between levels of SES components and levels of adherence to antiretroviral treatment, although one for income (59), four for education $(21,31,43,63)$ and two for employment $(59,77)$ of the reviewed studies suggest an inverse association with adherence. However, the aforementioned SES determinants were not found to be significantly associated with adherence in relation to 20 income-related studies $(71,73,23,24,25,30,34-$ $36,42,43,45,57,61,77), 35$ education-related studies $(22-25,27,29,32,34,36,38,42,44,45,47-52$, $60,64,67,70,74,76,78-81,82), 22$ employment/ occupational status-related studies (22-24,34$36,41,42,44,45,49,53,54,58,67-70,78,79,81,82)$ and two SES-related studies $(40,78)$ (Table 2$)$.

\section{Limitations}

This systematic review has several limitations. First, it was not possible to make a synthesis of the data, using the principles of meta-analysis due to the fact that there was considerable heterogeneity among the reviewed studies. Adherence was measured by different methods in each of the studies and the cutoff percentage of adherence to treatment between 'adherent' and 'non-adherent' varied among the studies. Another limitation was that the majority of the studies examined the used unreliable measures of adherence (self-report, in particular) as the adherence outcome measure. In addition, SES was not focused upon as a homogenous group of specific factors in most of the reviewed studies but was rather dispersed among its components, which were regarded as socioeconomic information. Therefore, partial data had to be collected regarding the association of such SES components, and adherence to antiretroviral therapy, where and if such an association was assessed. Occupation was mainly assessed in terms of employment status because often no data were given on status of occupation or working position of the patients (8).

\section{Conclusions}

The systematic review of the available evidence found a positive trend among components of SES (income, education, occupation/employment) and adherence to antiretroviral therapy in many of the reviewed studies. However, we found inconclusive support for a clear association between SES and adherence among patients infected with HIV/AIDS in low- and middle-income countries. The association between SES and adherence may differ depending on the cultural/economic/geographic context of the countries studied, and results emphasize a site-specific approach to adherence studies and programmes. Future studies should measure socioeconomic factors more accurately and, thus, may further explain the different impacts of SES to ART adherence. In the absence of a gold standard for measure of adherence, future studies should assess many outcomes.

\section{REFERENCES}

1. Kredo T, Van der Walt JS, Siegfried N, Cohen K. Therapeutic drug monitoring of antiretrovirals for people with HIV. Cochrane Database Syst Rev 2009;(3):CD007268.

2. Lohse N, Hansen AB, Gerstoft J, Obel N. Improved survival in HIV-infected persons: consequences and perspectives. J Antimicrob Chemother 2007;60:461-3.

3. Vergidis PI, Falagas ME, Hamer DH. Meta-analytical studies on the epidemiology, prevention, and treatment of human immunodeficiency virus infection. Infect Dis Clin North Am 2009;23:295-308.

4. Lima VD, Harrigan R, Murray M, Moore DM, Wood E, Hogg RS et al. Differential impact of adherence on long-term treatment response among naive HIV-infected individuals. AIDS 2008;22:2371-80.

5. Bangsberg DR. Less than $95 \%$ adherence to nonnucleoside reverse-transcriptase inhibitor therapy can lead to viral suppression. Clin Infect Dis 2006;43:939-41. 
6. Shuter J, Sarlo JA, Kanmaz TJ, Rode RA, Zingman BS. HIV-infected patients receiving lopinavir/ritonavirbased antiretroviral therapy achieve high rates of virologic suppression despite adherence rates less than 95\%. J Acquir Immune Defic Syndr 2007;45:4-8.

7. Knafl GJ, Bova CA, Fennie KP, O'Malley JP, Dieckhaus $\mathrm{KD}$, Williams AB. An analysis of electronically monitored adherence to antiretroviral medications. AIDS Behav 2010;14:755-68.

8. Falagas ME, Zarkadoulia EA, Pliatsika PA, Panos G. Socioeconomic status (SES) as a determinant of adherence to treatment in HIV infected patients: a systematic review of the literature. Retrovirology 2008;5:13.

9. Atkinson MJ, Petrozzino JJ. An evidence-based review of treatment-related determinants of patients' nonadherence to HIV medications. AIDS Patient Care STDS 2009;23:903-14.

10. Ammassari A, Trotta MP, Murri R, Castelli F, Narciso $\mathrm{P}$, Noto $\mathrm{P}$ et al. Correlates and predictors of adherence to highly active antiretroviral therapy: overview of published literature. I Acquir Immune Defic Syndr 2002;31(Suppl 3):S123-7.

11. World Bank. Country classification 2010. Washington, DC: World Bank, 2010. 14 p. (http://www.anz. com/resources/2/f/2f41378049578330ac47fffc8cff90 cd/OECD-definition.pdf?CACHEID=2f41378049578 330ac47fffc8cff90cd, accessed on 12 October 2011).

12. Wojcicki JM. Socioeconomic status as a risk factor for HIV infection in women in East, Central and Southern Africa: a systematic review. J Biosoc Sci 2005;37:1-36.

13. Krieger N, Williams DR, Moss NE. Measuring social class in US public health research: concepts, methodologies, and guidelines. Annu Rev Public Health 1997;18:341-78.

14. Adler NE, Ostrove JM. Socioeconomic status and health: what we know and what we don't. Ann NY Acad Sci 1999;896:3-15.

15. Kawachi I, Subramanian SV, Almeida-Filho N. A glossary for health inequalities. I Epidemiol Community Health 2002;56:647-52.

16. Galobardes B, Shaw M, Lawlor DA, Lynch JW, Davey Smith G. Indicators of socioeconomic position (part 1). J Epidemiol Community Health 2006;60:7-12.

17. Azar MM, Springer SA, Meyer JP, Altice FL. A systematic review of the impact of alcohol use disorders on HIV treatment outcomes, adherence to antiretroviral therapy and health care utilization. Drug Alcohol Depend 2010;112:178-93.

18. Malta M, Strathdee SA, Magnanini MMF, Bastos FI. Adherence to antiretroviral therapy for human immunodeficiency virus/acquired immune deficiency syndrome among drug users: a systematic review. Addiction 2008;103:1242-57.

19. Chander G, Himelhoch S, Moore RD. Substance abuse and psychiatric disorders in HIV-positive pa- tients: epidemiology and impact on antiretroviral therapy. Drugs 2006;66:769-89.

20. World Health Organization. World health statistics 2011. Geneva: World Health Organization, 2011. 170 p.

21. Weiser S, Wolfe W, Bangsberg D, Thior I, Gilbert P, Makhema J et al. Barriers to antiretroviral adherence for patients living with HIV infection and AIDS in Botswana. J Acquir Immune Defic Syndr 2003;34:281-8.

22. Do NT, Phiri K, Bussmann H, Gaolathe T, Marlink RG, Wester CW. Psychosocial factors affecting medication adherence among HIV-1 infected adults receiving combination antiretroviral therapy (cART) in Botswana. AIDS Res Hum Retroviruses 2010;26:685-91.

23. Gust DA, Mosimaneotsile B, Mathebula U, Chingapane B, Gaul Z, Pals SL et al. Risk factors for non-adherence and loss to follow-up in a three-year clinical trial in Botswana. PLoS One 2011;6:e18435.

24. Boyer S, Marcellin F, Ongolo-Zogo P, Abega S-C, Nantchouang R, Spire B et al. Financial barriers to HIV treatment in Yaoundé, Cameroon: first results of a national cross-sectional survey. Bull World Health Organ 2009;87:279-87.

25. Rougemont M, Stoll BE, Elia N, Ngang P. Antiretroviral treatment adherence and its determinants in SubSaharan Africa: a prospective study at Yaounde Central Hospital, Cameroon. AIDS Res Ther 2009;6:21.

26. Boyer S, Clerc I, Bonono C-R, Marcellin F, Bilé P-C, Ventelou B. Non-adherence to antiretroviral treatment and unplanned treatment interruption among people living with HIV/AIDS in Cameroon: individual and healthcare supply-related factors. Soc Sci Med 2011;72:1383-92.

27. Roux P, Kouanfack C, Cohen J, Marcellin F, Boyer S, Delaporte E et al. Adherence to antiretroviral treatment in HIV-positive patients in the Cameroon context: promoting the use of medication reminder methods. J Acquir Immune Defic Syndr 2011;57 (Suppl 1):S40-3.

28. Beyene KA, Gedif T, Gebre-Mariam T, Engidawork E. Highly active antiretroviral therapy adherence and its determinants in selected hospitals from south and central Ethiopia. Pharmacoepidemiol Drug Saf 2009;18:1007-15.

29. Giday A, Shiferaw W. Factors affecting adherence of antiretroviral treatment among AIDS patients in an Ethiopian tertiary university teaching hospital. Ethiop Med J 2010;48:187-94.

30. Tiyou A, Belachew T, Alemseged F, Biadgilign S. Predictors of adherence to antiretroviral therapy among people living with HIV/AIDS in resource-limited setting of southwest ethiopia. AIDS Res Ther 2010;7:39.

31. Eholié SP, Tanon A, Polneau S, Ouiminga M, Djadji A, Kangah-Koffi $\mathrm{C}$ et al. Field adherence to highly active antiretroviral therapy in HIV-infected adults in Abidjan, Côte d'Ivoire. J Acquir Immune Defic Syndr 2007;45:355-8. 
32. Unge C, Södergård B, Marrone G, Thorson A, Lukhwaro A, Carter J et al. Long-term adherence to antiretroviral treatment and program drop-out in a highrisk urban setting in sub-Saharan Africa: a prospective cohort study. PLoS One 2010;5:e13613.

33. Iliyasu Z, Kabir M, Abubakar IS, Babashani M, Zubair ZA. Compliance to antiretroviral therapy among AIDS patients in Aminu Kano Teaching Hospital, Kano, Nigeria. Niger J Med 2005;14:290-4.

34. Shaahu VN, Lawoyin TO, Sangowawa AO. Adherence to highly active antiretroviral therapy (HAAT) at a Federal Medical Centre. Afr J Med Med Sci 2008;37:29-36.

35. Uzochukwu BSC, Onwujekwe OE, Onoka AC, Okoli C, Uguru NP, Chukwuogo OI. Determinants of nonadherence to subsidized anti-retroviral treatment in southeast Nigeria. Health Policy Plan 2009;24:189-96.

36. Adewuya AO, Afolabi MO, Ola BA, Ogundele OA, Ajibare AO, Oladipo BF et al. The effect of psychological distress on medication adherence in persons with HIV infection in Nigeria. Psychosomatics 2010;51:6873.

37. Alakija Kazeem Salami, Fadeyi A, Ogunmodede JA, Desalu O. Factors influencing adherence to antiretroviral medication in Ilorin, Nigeria. J Int Assoc Physicians AIDS Care (Chic) 2010;9:191-5.

38. Ukwe CV, Ekwunife OI, Udeogaranya OP, Iwuamadi UI. Self-reported adherence to HAART in South-Eastern Nigeria is related to patients' use of pill box. $S A$ HARA J 2010;7:10-5.

39. Lanièce I, Ciss M, Desclaux A, Diop K, Mbodj F, Ndiaye $\mathrm{B}$ et al. Adherence to HAART and its principal determinants in a cohort of Senegalese adults. AIDS 2003;17(Suppl 3):S103-8.

40. Orrell C, Bangsberg DR, Badri M, Wood R. Adherence is not a barrier to successful antiretroviral therapy in South Africa. AIDS 2003;17:1369-75.

41. Nachega JB, Stein DM, Lehman DA, Hlatshwayo D, Mothopeng R, Chaisson RE et al. Adherence to antiretroviral therapy in HIV-infected adults in Soweto, South Africa. AIDS Res Hum Retroviruses 2004;20:1053-6.

42. Malangu NG. Self-reported adverse effects as barriers to adherence to antiretroviral therapy in HIV-infected patients in Pretoria. SA Fam Pract 2008;50:49.

43. Maqutu D, Zewotir T, North D, Naidoo K, Grobler A. Factors affecting first-month adherence to antiretroviral therapy among HIV-positive adults in South Africa. Afr J AIDS Res 2010;9:117-124.

44. Peltzer K, Friend-du Preez N, Ramlagan S, Anderson J. Antiretroviral treatment adherence among HIV patients in KwaZulu-Natal, South Africa. BMC Public Health 2010;10:111.

45. Peltzer K, Friend-du Preez N, Ramlagan S, Fomundam $\mathrm{H}$, Anderson J, Chanetsa L. Antiretrovirals and the use of traditional, complementary and alternative medicine by HIV patients in Kwazulu-Natal, South
Africa: a longitudinal study. Afr J Tradit Complement Altern Med 2011;8:337-45.

46. Ramadhani HO, Thielman NM, Landman KZ, Ndosi EM, Gao F, Kirchherr JL et al. Predictors of incomplete adherence, virologic failure, and antiviral drug resistance among HIV-infected adults receiving antiretroviral therapy in Tanzania. Clin Infect Dis 2007;45:1492-8.

47. Watt MH, Maman S, Golin CE, Earp JA, Eng E, Bangdiwala SI et al. Factors associated with self-reported adherence to antiretroviral therapy in a Tanzanian setting. AIDS Care 2010;22:381-9.

48. Hegazi A, Bailey RL, Ahadzie B, Alabi A, Peterson K. Literacy, education and adherence to antiretroviral therapy in The Gambia. AIDS Care 2010;22:1340-5.

49. Byakika-Tusiime J, Oyugi JH, Tumwikirize WA, Katabira ET, Mugyenyi PN, Bangsberg DR. Adherence to HIV antiretroviral therapy in HIV+ Ugandan patients purchasing therapy. Int J STD AIDS 2005;16:38-41.

50. Abaasa AM, Todd J, Ekoru K, Kalyango JN, Levin J, Odeke E et al. Good adherence to HAART and improved survival in a community HIV/AIDS treatment and care programme: the experience of The AIDS Support Organization (TASO), Kampala, Uganda. BMC Health Serv Res 2008;8:241.

51. Bajunirwe F, Arts EJ, Tisch DJ, King CH, Debanne SM, Sethi AK. Adherence and treatment response among HIV-1-infected adults receiving antiretroviral therapy in a rural government hospital in Southwestern Uganda. J Int Assoc Physicians AIDS Care (Chic) 2009;8:139-47.

52. Byakika-Tusiime J, Crane J, Oyugi JH, Ragland K, Kawuma A, Musoke P et al. Longitudinal antiretroviral adherence in HIV+ Ugandan parents and their children initiating HAART in the MTCT-Plus family treatment model: role of depression in declining adherence over time. AIDS Behav 2009;13(Suppl 1):82-91.

53. Nakimuli-Mpungu E, Mutamba B, Othengo M, Musisi S. Psychological distress and adherence to highly active anti-retroviral therapy (HAART) in Uganda: a pilot study. Afr Health Sci 2009;9(Suppl 1):S2-7.

54. Kunutsor S, Walley J, Katabira E, Muchuro S, Balidawa H, Namagala E et al. Clinic Attendance for Medication Refills and Medication Adherence amongst an Antiretroviral Treatment Cohort in Uganda: A Prospective Study. AIDS Res Treat 2010;2010:872396.

55. Carlucci JG, Kamanga A, Sheneberger R, Shepherd $\mathrm{BE}$, Jenkins CA, Spurrier J et al. Predictors of adherence to antiretroviral therapy in rural Zambia. J Acquir Immune Defic Syndr 2008;47:615-22.

56. Birbeck GL, Chomba E, Kvalsund M, Bradbury R, Mang'ombe C, Malama K et al. Antiretroviral adherence in rural Zambia: the first year of treatment availability. Am J Trop Med Hyg 2009;80:669-74.

57. Birbeck GL, Kvalsund MP, Byers PA, Bradbury R, Mang'ombe C, Organek N et al. Neuropsychiatric 
and socioeconomic status impact antiretroviral adherence and mortality in rural Zambia. Am J Trop Med Hyg 2011;85:782-9.

58. Aboubacrine SA, Niamba P, Boileau C, Zunzunegui $\mathrm{MV}$, Machouf N, Nguyen VK et al. Inadequate adherence to antiretroviral treatment and prevention in hospital and community sites in Burkina Faso and Mali: a study by the ATARAO group. Int J STD AIDS 2007;18:741-7.

59. Etienne M, Hossain M, Redfield R, Stafford K, Amoroso A. Indicators of adherence to antiretroviral therapy treatment among HIV/AIDS patients in 5 African countries. J Int Assoc Physicians AIDS Care (Chic) 2010;9:98-103.

60. Wang H, He G, Li X, Yang A, Chen X, Fennie KP et al. Self-Reported adherence to antiretroviral treatment among HIV-infected people in Central China. AIDS Patient Care STDS 2008;22:71-80.

61. Safren SA, Kumarasamy N, James R, Raminani S, Solomon S, Mayer KH. ART adherence, demographic variables and CD4 outcome among HIV-positive patients on antiretroviral therapy in Chennai, India. AIDS Care 2005;17:853-62.

62. Wanchu A, Kaur R, Bambery P, Singh S. Adherence to generic reverse transcriptase inhibitor-based antiretroviral medication at a Tertiary Center in North India. AIDS Behav 2007;11:99-102.

63. Sarna A, Pujari S, Sengar AK, Garg R, Gupta I, Dam Jv. Adherence to antiretroviral therapy \& its determinants amongst HIV patients in India. Indian J Med Res 2008;127:28-36.

64. Cauldbeck MB, O'Connor C, O'Connor MB, Saunders JA, Rao B, Mallesh VG et al. Adherence to antiretroviral therapy among HIV patients in Bangalore, India. AIDS Res Ther 2009;6:7.

65. Naik E, Casanas B, Pazare A, Wabale G, Sinnott J, Salihu H. Cost of treatment: The single biggest obstacle to HIV/AIDS treatment adherence in lower-middle class patients in Mumbai, India. Indian J Sex Transm Dis 2009;30:23-7.

66. Batavia AS, Balaji K, Houle E, Parisaboina S, Ganesh $\mathrm{AK}$, Mayer $\mathrm{KH}$ et al. Adherence to antiretroviral therapy in patients participating in a graduated cost recovery program at an HIV care center in South India. AIDS Behav 2010;14:794-8.

67. Lal V, Kant S, Dewan R, Rai SK, Biswas A. A two-site hospital-based study on factors associated with nonadherence to highly active antiretroviral therapy. Indian J Public Health 2010;54:179-83.

68. Venkatesh KK, Srikrishnan AK, Mayer KH, Kumarasamy N, Raminani S, Thamburaj E et al. Predictors of nonadherence to highly active antiretroviral therapy among HIV-infected South Indians in clinical care: implications for developing adherence interventions in resource-limited settings. AIDS Patient Care STDS 2010;24:795-803.
69. Kelly A, Worth H, Man N, Nosi S, Emori R, Mek A et al. Barriers and facilitators for adherence to antiretroviral therapy in Papua New Guinea. Curr HIV Res 2010;8:630-7.

70. Li L, Lee S-J, Wen Y, Lin C, Wan D, Jiraphongsa C. Antiretroviral therapy adherence among patients living with HIV/AIDS in Thailand. Nurs Health Sci 2010;12:212-20.

71. Pinheiro CAT, de-Carvalho-Leite JC, Drachler ML, Silveira VL. Factors associated with adherence to antiretroviral therapy in HIV/AIDS patients: a crosssectional study in Southern Brazil. Braz J Med Biol Res 2002;35:1173-81.

72. Nemes MI, Carvalho HB, Souza MF. Antiretroviral therapy adherence in Brazil. AIDS 2004;18(Suppl 3): S15-20.

73. de Carvalho CV, Merchán-Hamann E, Matsushita R. [Determinants of antiretroviral treatment adherence in Brasília, Federal District: a case-control study]. Rev Soc Bras Med Trop 2007;40:555-65. [Portuguese]

74. Seidl EM, Melchíades A, Farias V, Brito A. [Persons living with HIV/AIDS: factors associated with adherence to antiretroviral treatment]. Cad Saude Publica 2007;23:2305-16. [Portuguese]

75. Blatt CR, Citadin CB, Souza FG, Mello RS, Galato D. [Assessment of adherence to antiretroviral drugs in a municipality in southern Brazil]. Rev Soc Bras Med Trop 2009;42:131-6. [Portuguese]

76. Silva MC, Ximenes RA, Miranda Filho DB, Arraes LW, Mendes M, Melo AC et al. Risk-factors for non-adherence to antiretroviral therapy. Rev Inst Med Trop Sao Paulo 2009;51:135-9.

77. Campos LN, Guimarães MDC, Remien RH. Anxiety and depression symptoms as risk factors for nonadherence to antiretroviral therapy in Brazil. AIDS Behav 2010;14:289-99.

78. Arrivillaga M, Ross M, Useche B, Alzate ML, Correa D. Social position, gender role, and treatment adherence among Colombian women living with HIV/AIDS: social determinants of health approach. Rev Panam Salud Publica 2009;26:502-10.

79. Stout BD, Leon MP, Niccolai LM. Nonadherence to antiretroviral therapy in HIV-positive patients in Costa Rica. AIDS Patient Care STDS 2004;18:297-304.

80. Aragonés C, Sánchez L, Campos JR, Pérez J. Antiretroviral therapy adherence in persons with HIV/AIDS in Cuba. MEDICC Rev 2011;13:17-23.

81. Harris J, Pillinger M, Fromstein D, Gomez B, Garris I, Kanetsky PA et al. Risk factors for medication nonadherence in an HIV infected population in the Dominican Republic. AIDS Behav 2011;15:1410-5.

82. Williams M, Clarke T, Williams P, Barton EN. The mean levels of adherence and factors contributing to non-adherence in patients on highly active antiretroviral therapy. West Indian Med J 2007;56:270-4. 


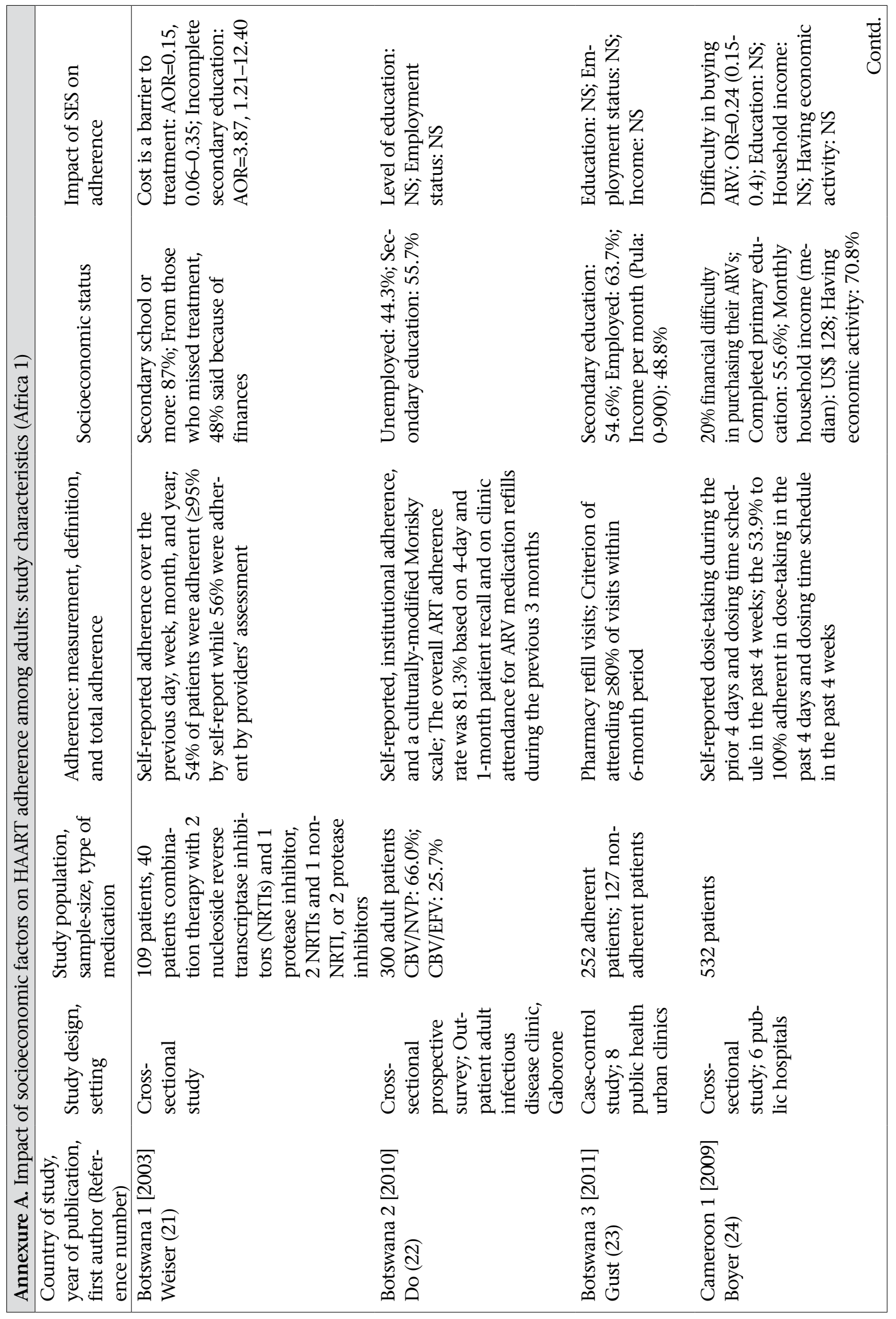




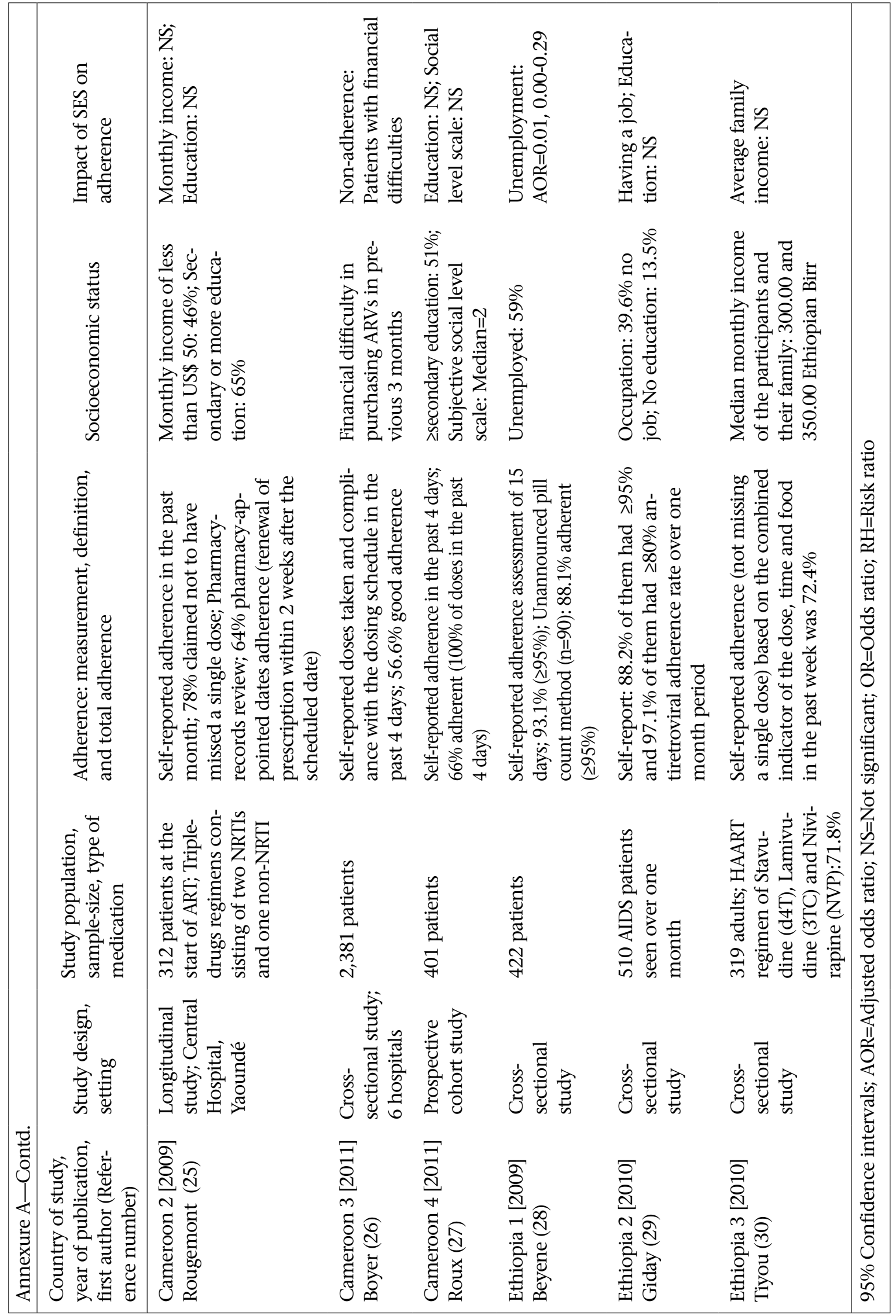




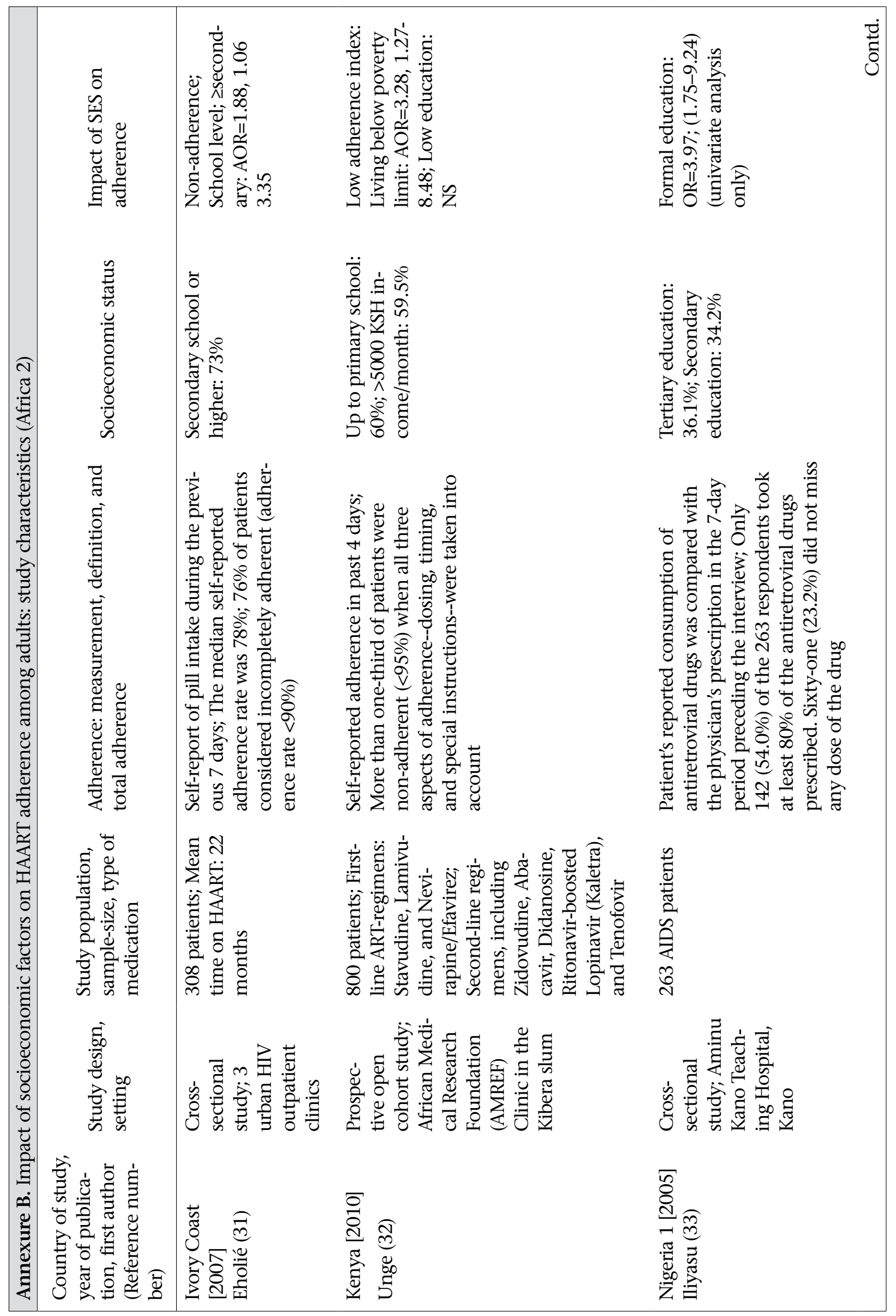




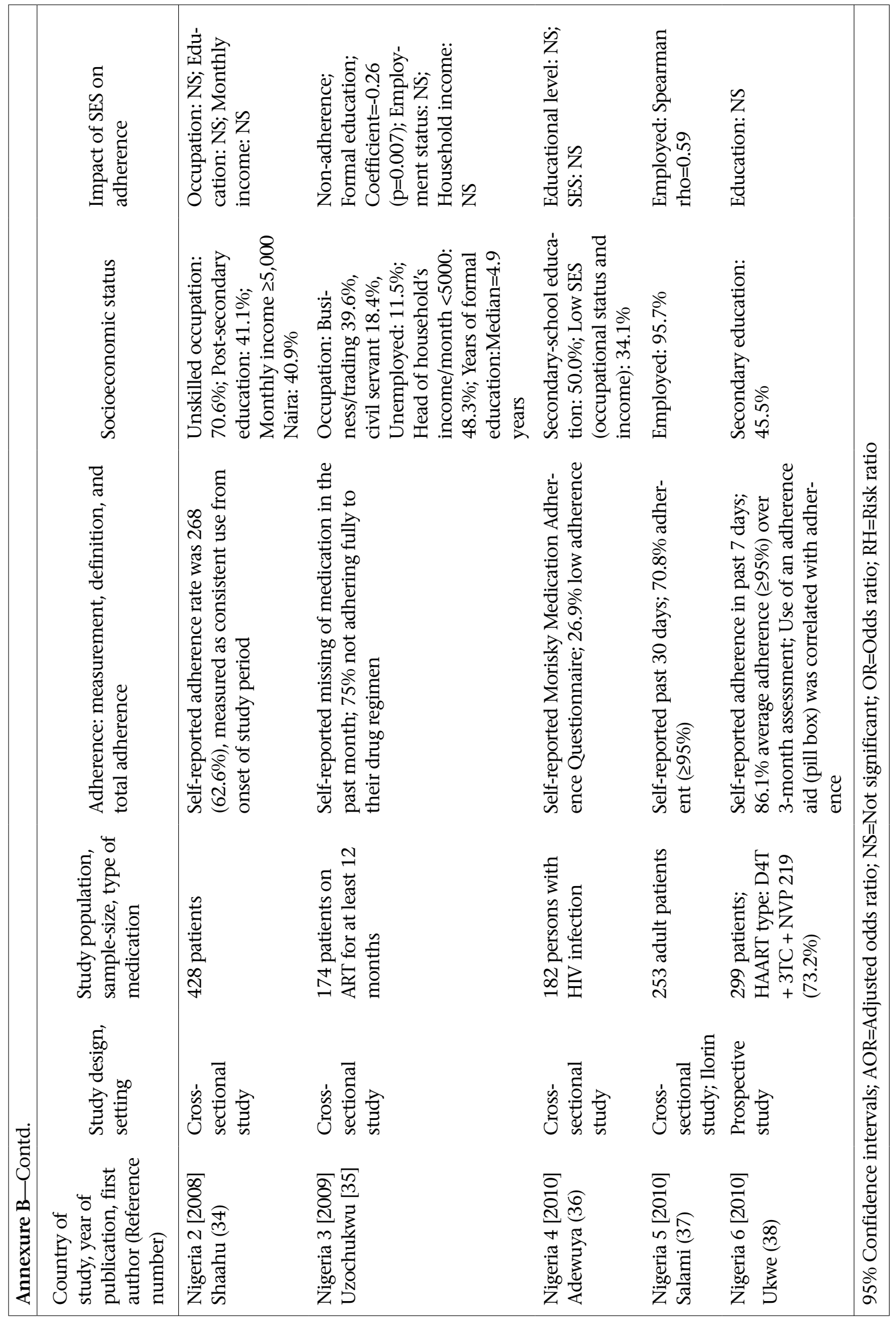




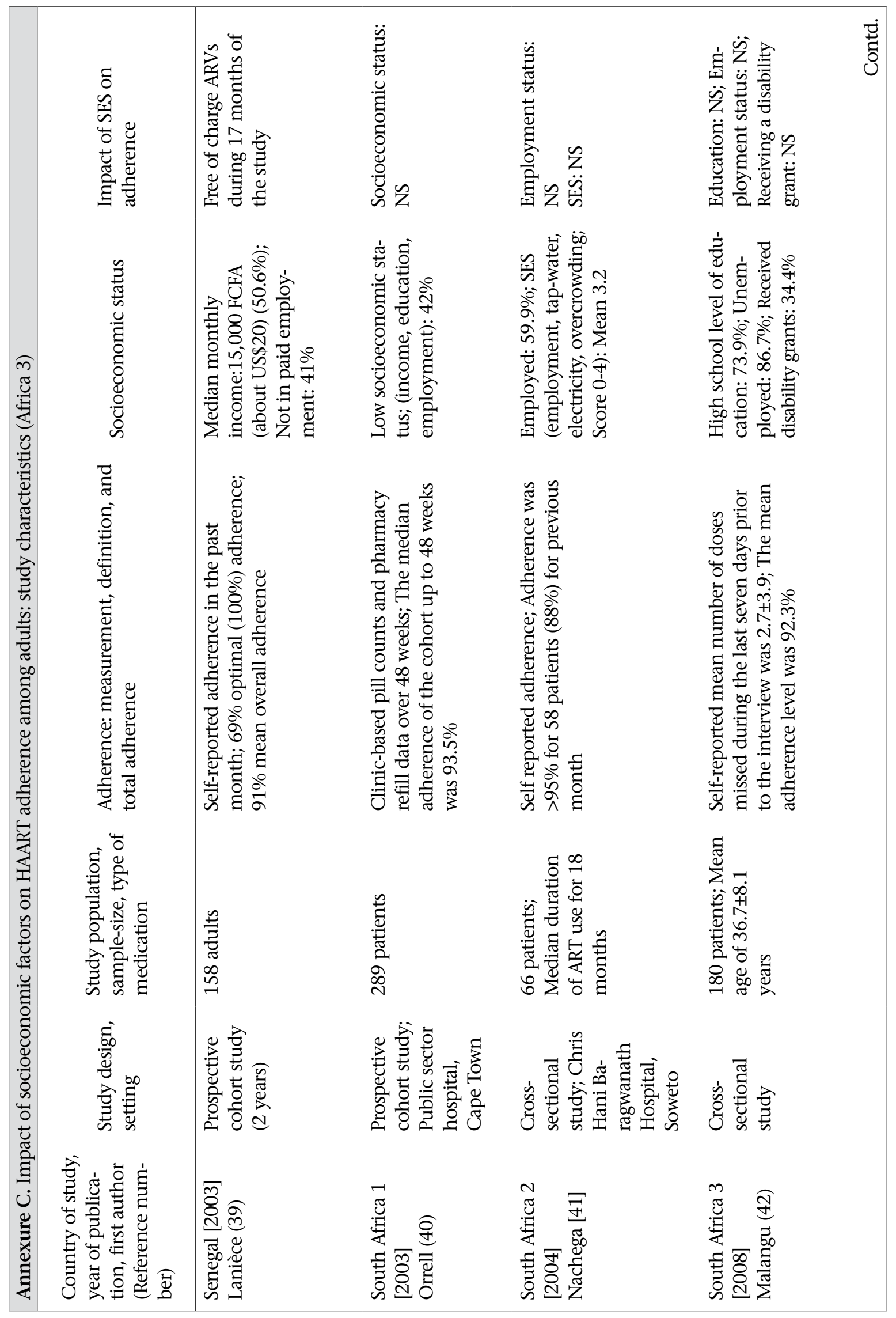




\begin{tabular}{|c|c|c|c|c|c|}
\hline 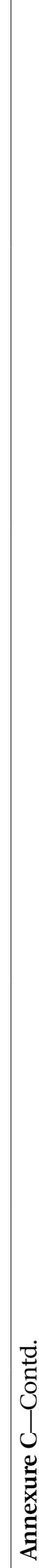 & 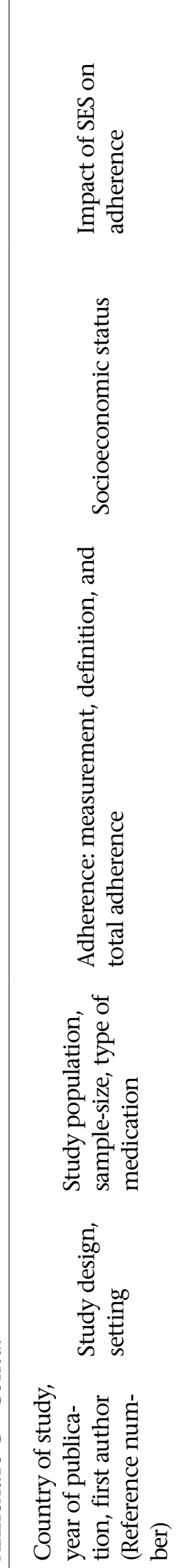 & 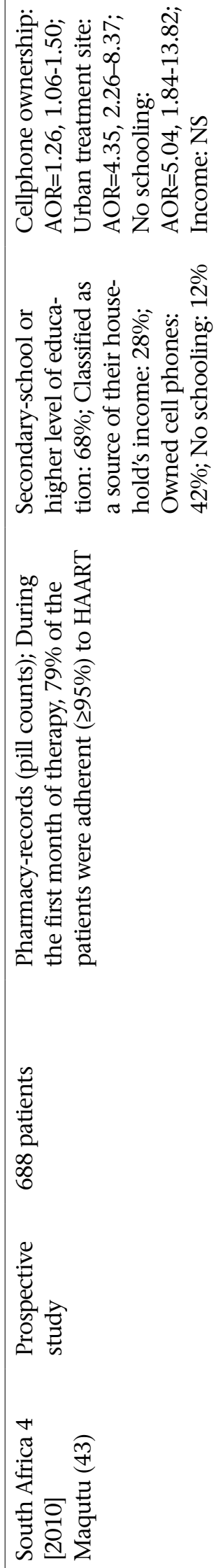 & 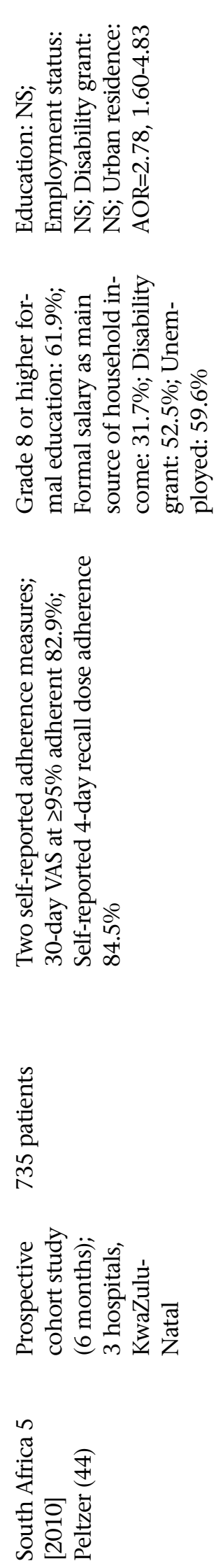 & 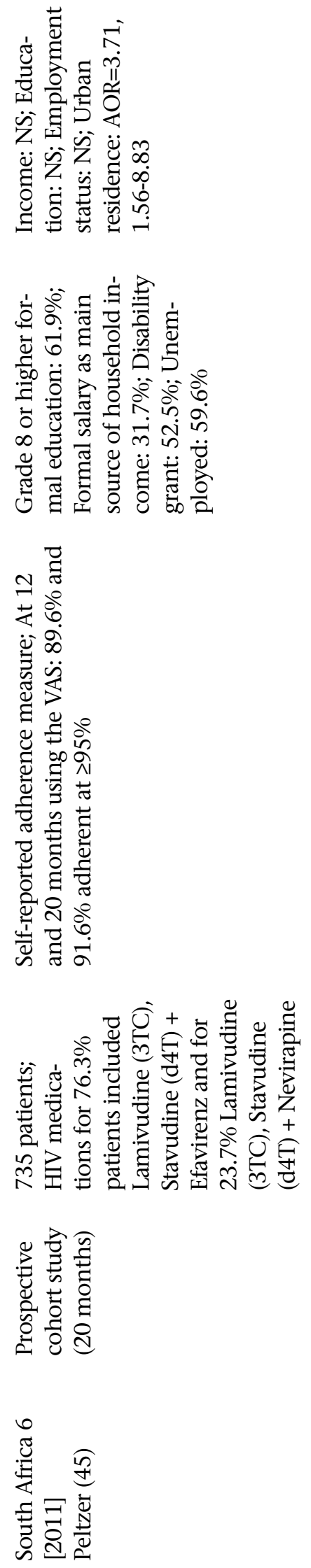 & 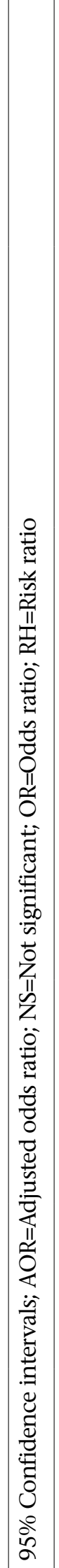 \\
\hline
\end{tabular}




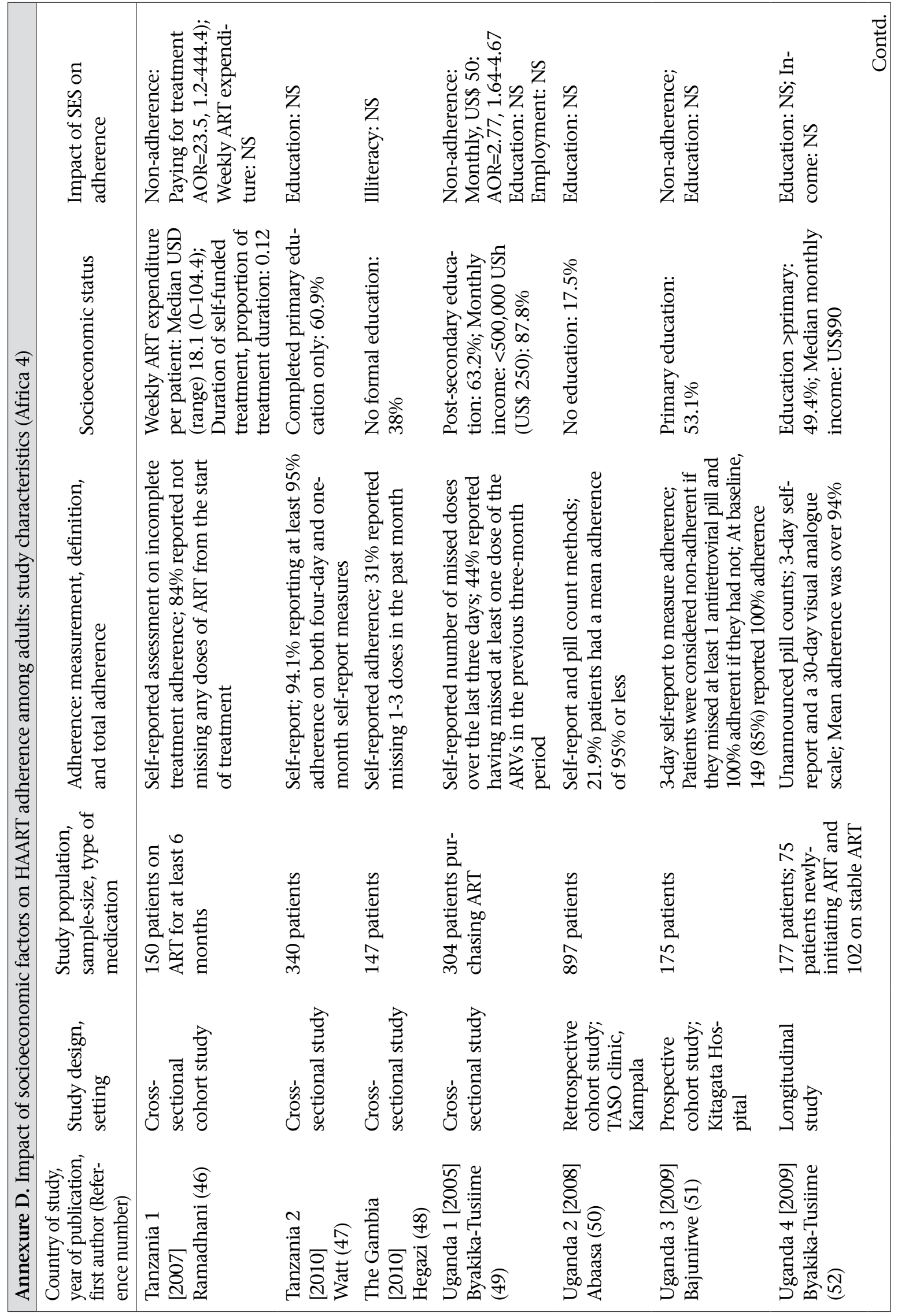




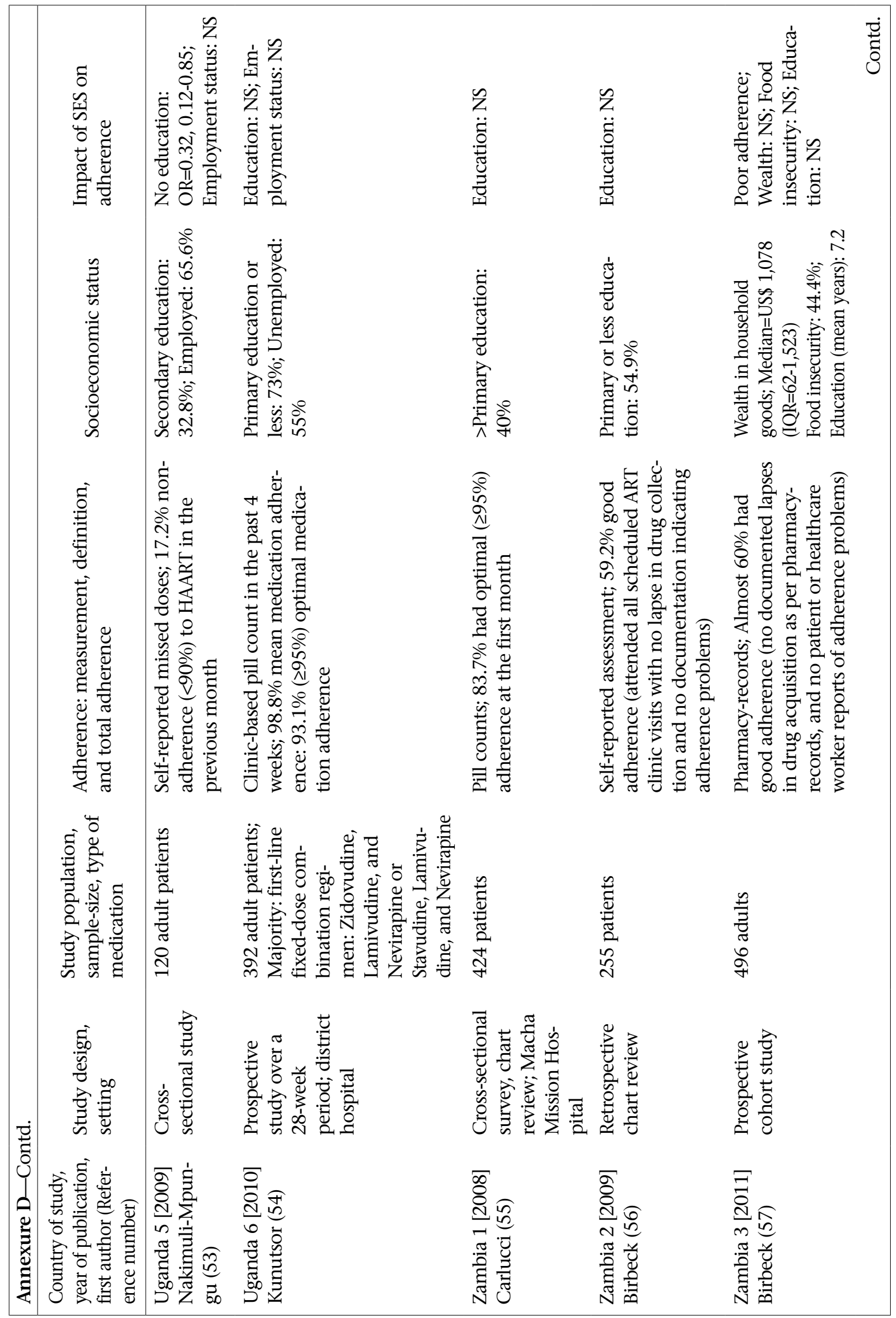




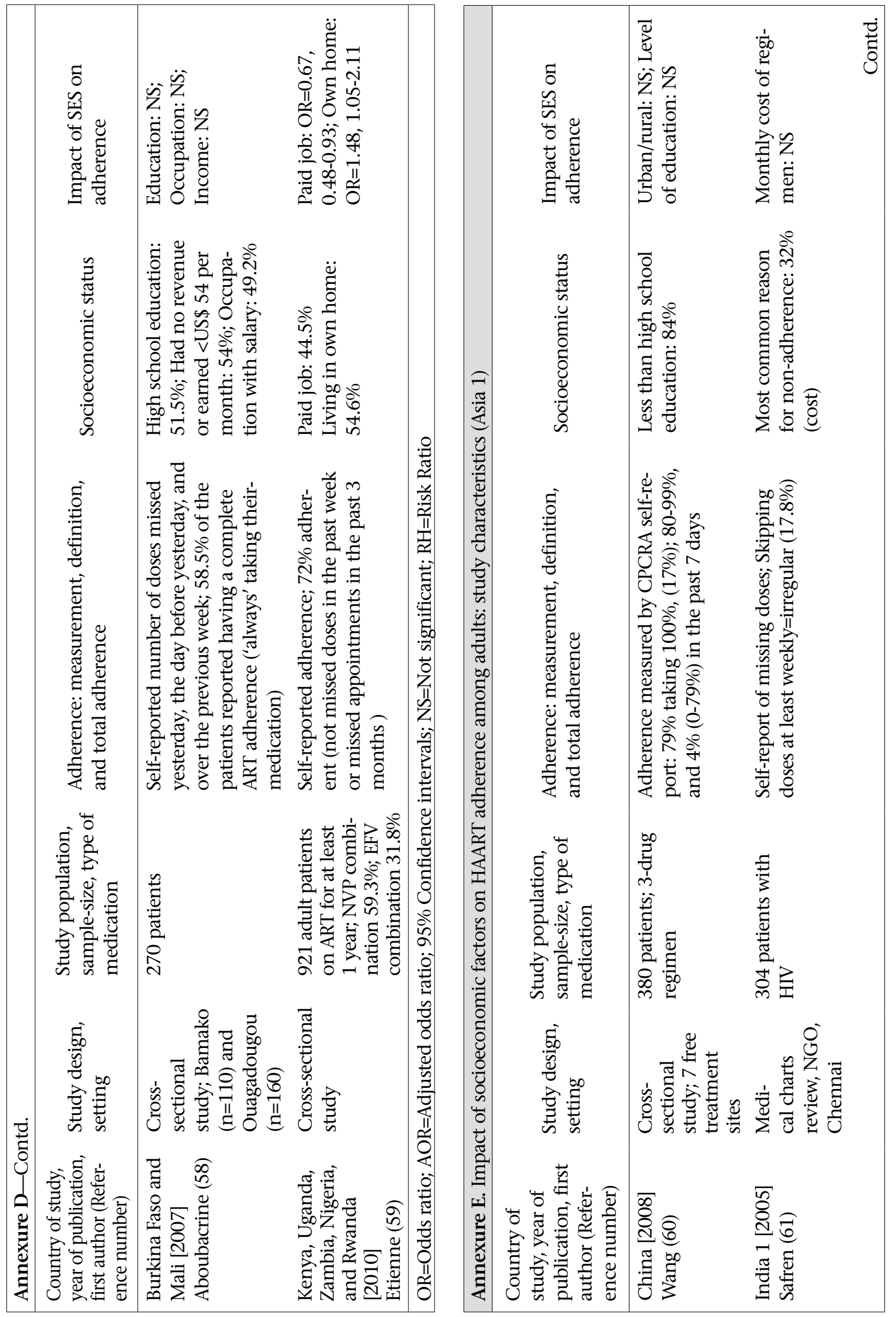




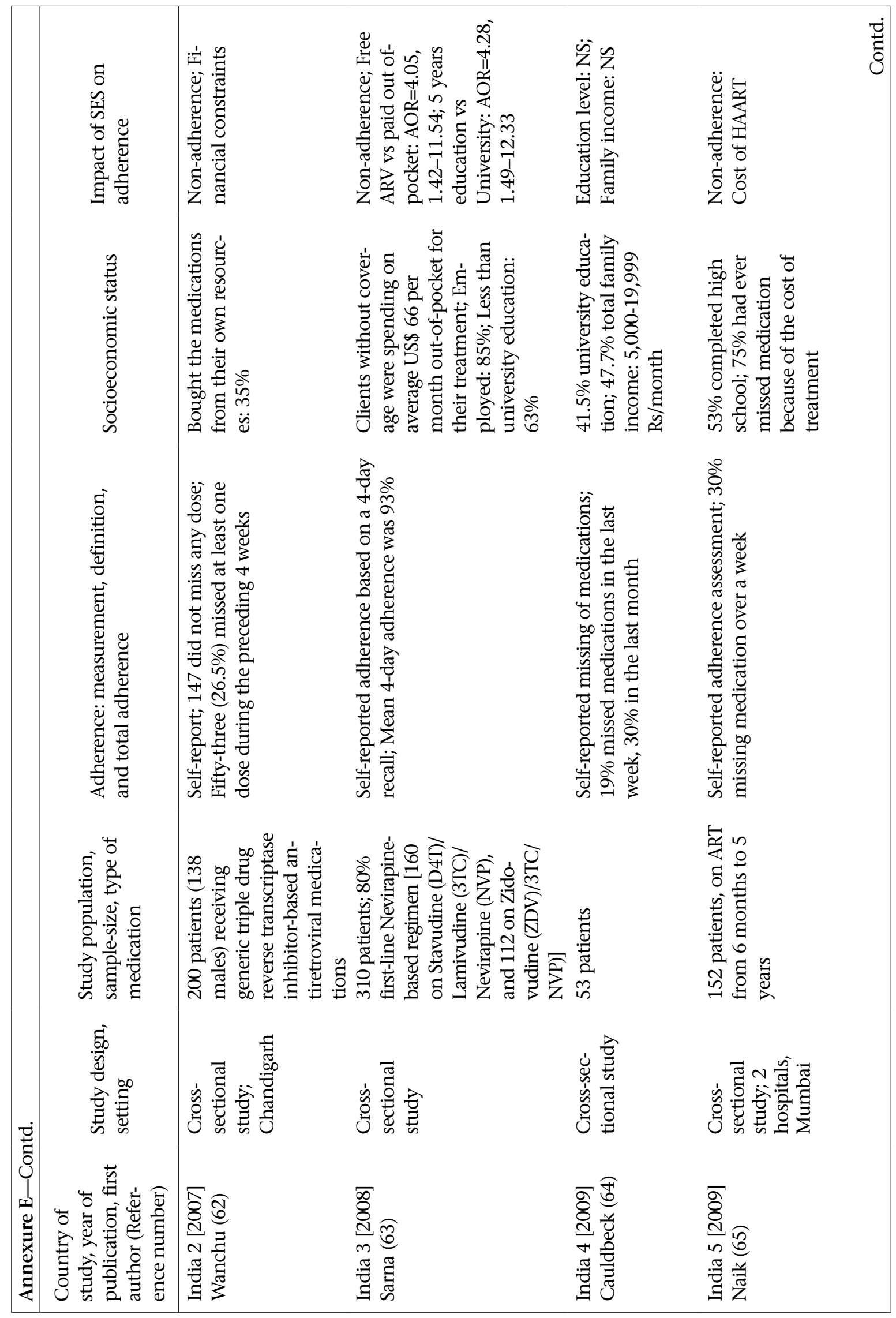




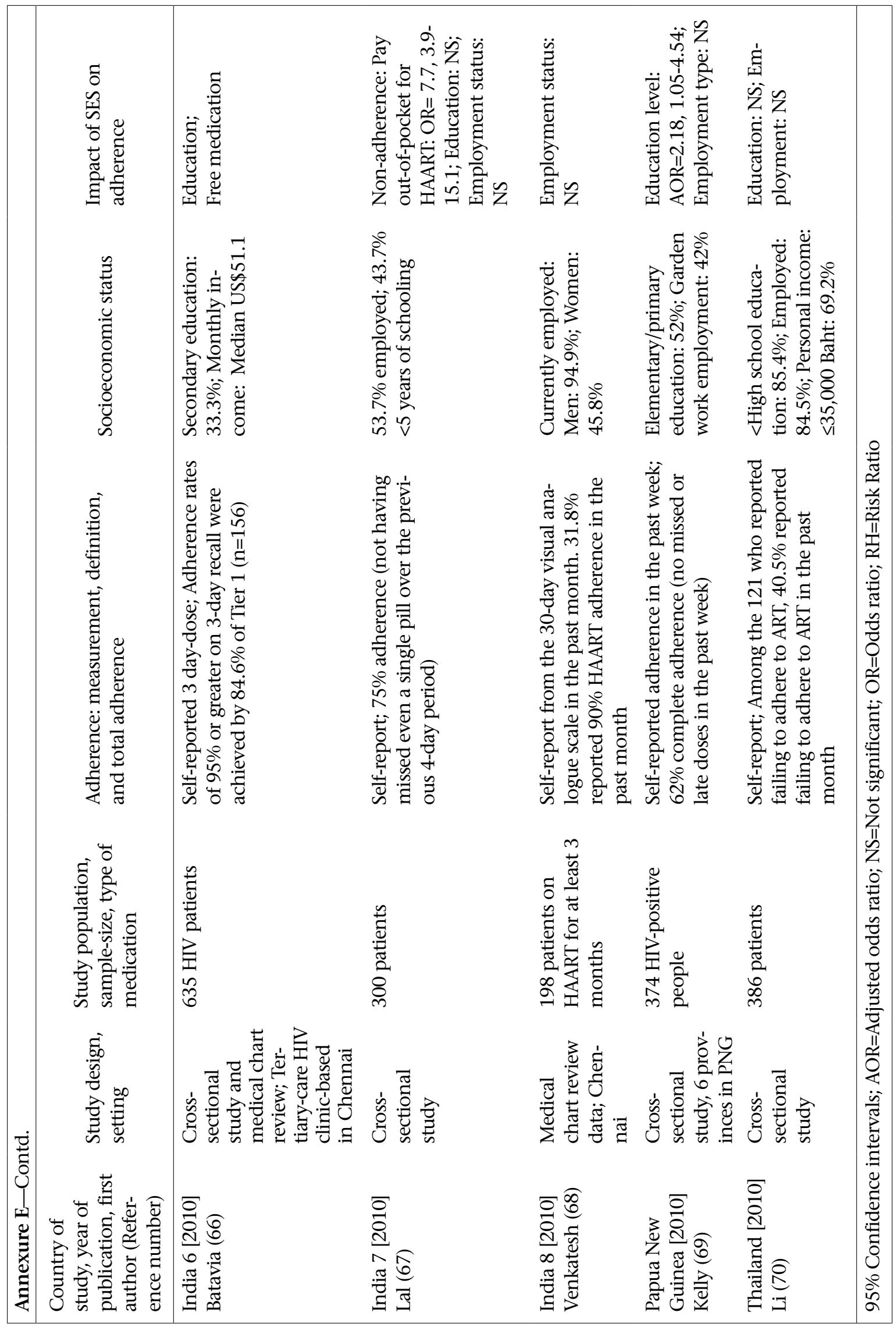




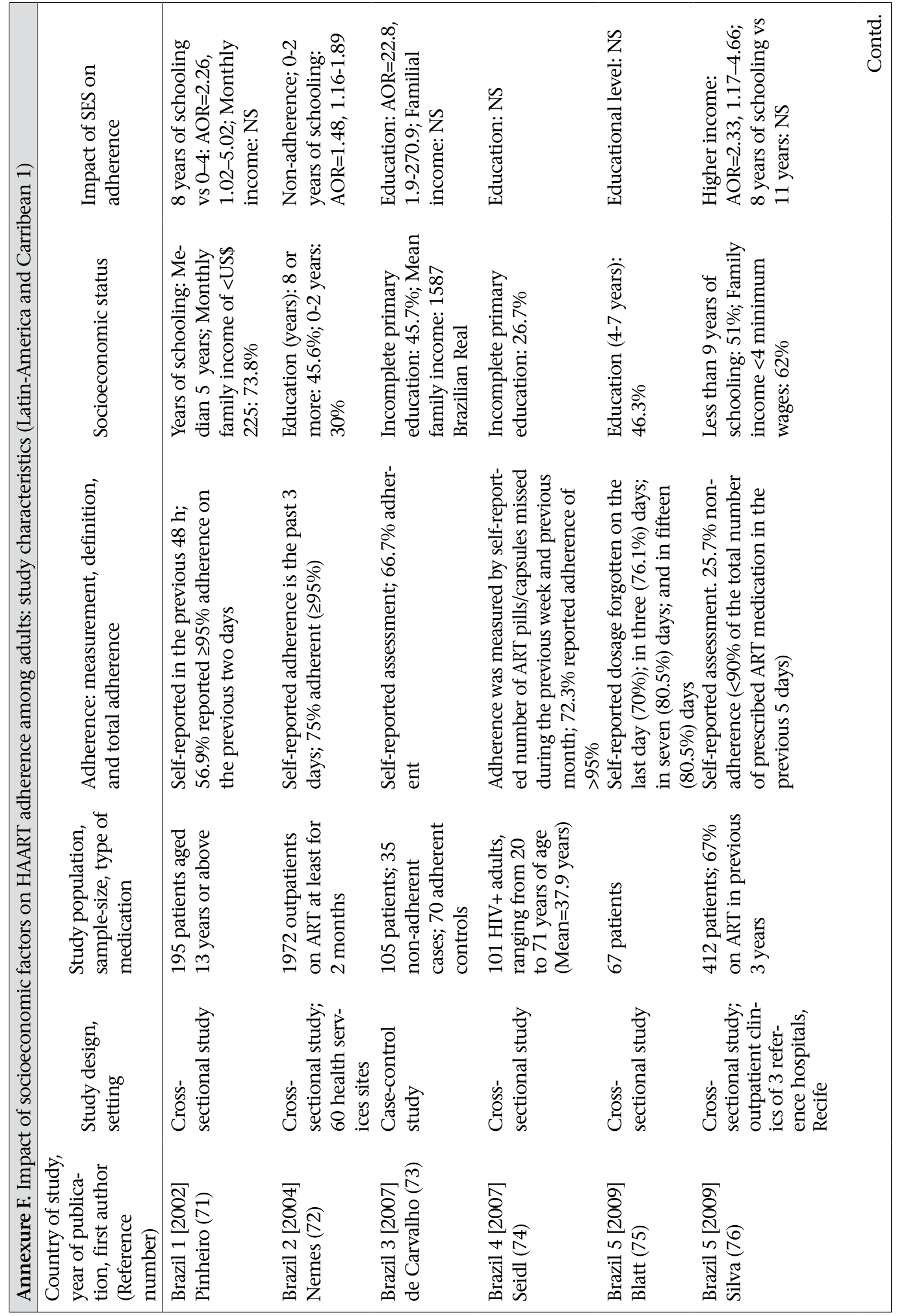




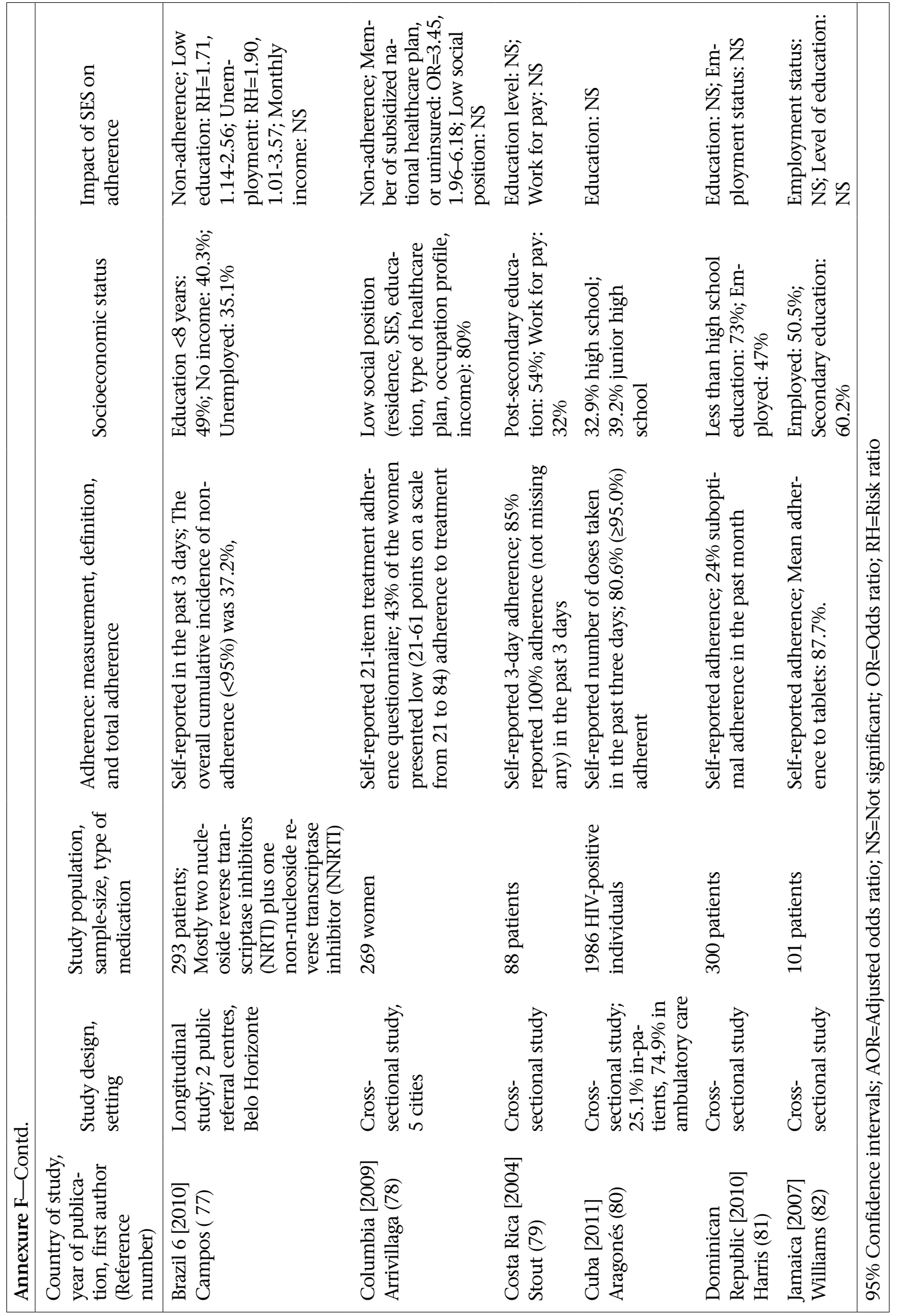

